\title{
Technologie laserowe spawania, wytwarzania i obróbki cieplnej warstw wierzchnich
}

\section{Laser welding, cladding and heat treatment technologies}

\section{Streszczenie}

W artykule opisano wyniki badań prowadzonych w firmie LaserTec nad opracowaniem przemysłowych warunków technologicznych spawania laserowego techniką z oczkiem spoiny oraz spawania hybrydowego laser + GMA wybranych złączy konstrukcji stalowych, napawania dużych powierzchni ekranów instalacji kotłowych, narzędzi górniczych oraz napawania regeneracyjnego krawędzi łopatek turbin, a także obróbki cieplnej warstw wierzchnich części ze stali narzędziowych.
Abstract

The article presents research results performed in company LaserTec. The studies were taken to elaborate industrial technological conditions of laser keyhole welding and laser hybrid welding laser + GMA of selected constructional steel joints, large area cladding of boiler elements, mining tools and regeneration cladding of turbine blades edges, as well as thermal treatment of surface layers of parts made of tool steel.

\section{Wstęp}

Promieniowanie laserowe i związany z tym termin (akronim) LASER uznaje się za jeden z najważniejszych wynalazków czasów nowożytnych, wywierających największy wpływ na rozwój techniczny i cywilizacyjny ludzkości. Genialny naukowiec i filozof Albert Einstein [1, 2] w 1917 r. ogłosił drukiem pracę teoretyczną na temat: mechaniki kwantowej, efektu fotoelektrycznego, kwantowej budowy światła i możliwości stymulacji emisji koherentnego, monochromatycznego promieniowania elekromagnetycznego, tworząc podstawy nowoczesnych spawalniczych technologii laserowych spawania, deponowania (napawania), stopowania, obróbki cieplnej, ablacji oraz cięcia.

Prof. dr hab. inż. Andrzej Klimpel - Politechnika Śląska, mgr inż. Aleksander Borek - SYSTEM, mgr inż. Ryszard Grzelka, mgr inż. Sebastian Mucha - Plasma SYSTEM, mgr inż. Bartłomiej Ścibisz - LaserTec.
Jedno z pierwszych zastosowań przemysłowych technologii laserowych $w$ spawalnictwie miało miejsce już na początku lat 70. ub.w., a było to cięcie laserem gazowym $\mathrm{CO}_{2}$ blach stalowych, zapewniające wyższą jakość i wydajność cięcia blach o grubości do $10 \div 15 \mathrm{~mm}$ niż w procesach cięcia tlenem i cięcia łukiem plazmowym [3]. Najnowsze rozwiązania konstrukcji generatorów wiązki laserowej, a zwłaszcza laserów na ciele stałym, prętowych, włóknowych i tarczowych (dyskowych), zapewniają coraz wyższe moce wiązki laserowej przy niższych kosztach urządzeń. Nowoczesne spawalnicze urządzenia laserowe dają możliwość dokładnej regulacji wszystkich parametrów wiązki laserowej, czyli: rodzaju promieniowania ciągłego, impulsowego lub udarowego (modów roboczych wiązki laserowej), kształtu i wymiarów ogniska, gęstości mocy, długości ogniskowej, a także śledzenia i sterowania torem przesuwu wiązki laserowej itd. [4].

Dodatkowo, stosunkowo proste i lekkie konstrukcje spawalniczych głowic laserowych sprawiają, że łatwa jest automatyzacja i robotyzacja procesów cięcia, 

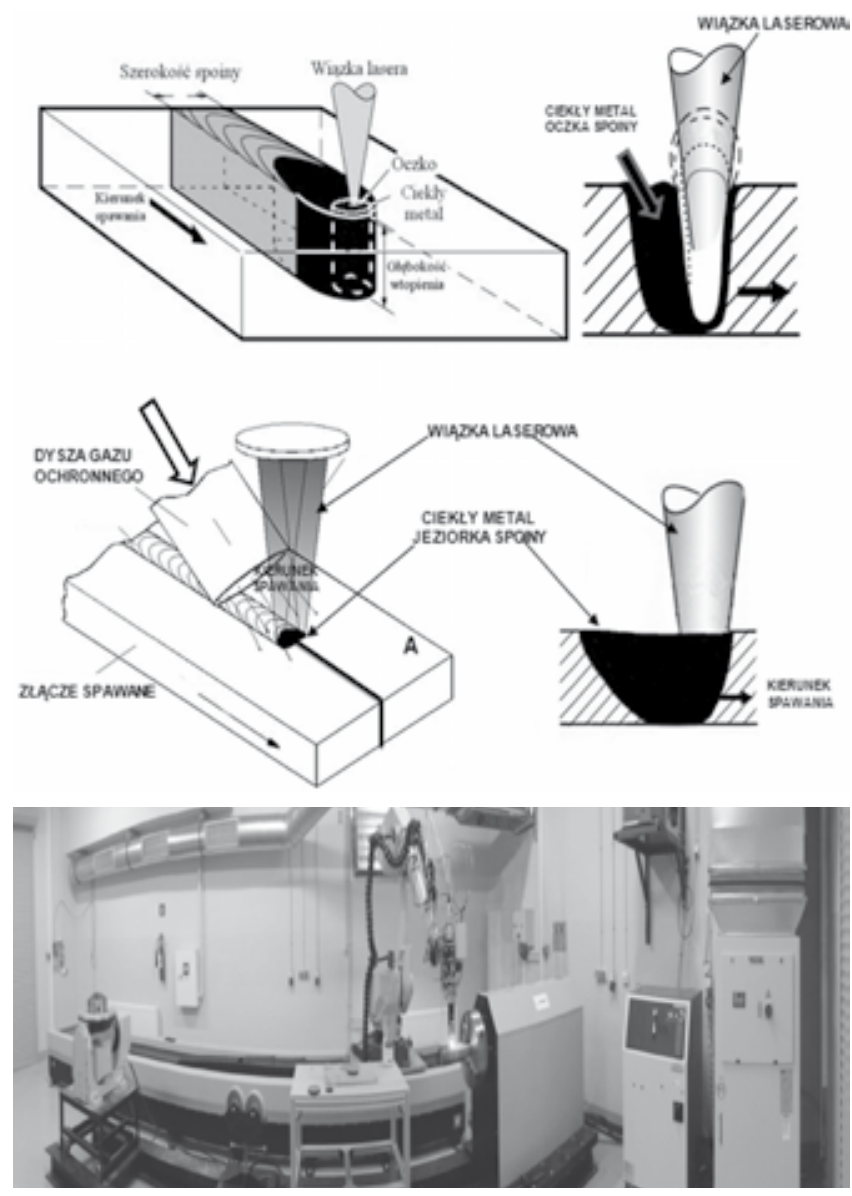

Rys. 1. Schemat spawania laserowego złącza doczołowego blach techniką z oczkiem spoiny i z jeziorkiem spoiny oraz widok stanowisk do spawania laserowego [6]

Fig. 1. Scheme of laser welding of butt joint with keyhole welding technique and with weld pool technique and view of a laser welding station [6]

przebijania, spawania, napawania, stopowania, czy obróbki cieplnej warstw wierzchnich. Przemysł światowy coraz powszechniej stosuje lasery do ręcznego lub półautomatycznego napawania warstw o małych powierzchniach $w$ trudno dostępnych miejscach oraz do czyszczenia ablacyjnego powierzchni różnorodnych konstrukcji, w zasadzie $z$ dowolnych materiałów inżynierskich. W przypadku produkcji seryjnej i masowej właśnie laserowe technologie spawalnicze są niezastąpione od kilkunastu lat $i$ to nie tylko $z$ uwagi na wysoką jakość tych procesów, ale i coraz wyższą opłacalność [4].

Spawanie laserowe złączy doczołowych, teowych, zakładkowych, narożnych, przylgowych, kołnierzowych, a więc w zasadzie wszystkich typowych złączy konstrukcji spawanych wykonanych ze spawalnych materiałów inżynierskich, polega na stapianiu obszaru łączenia ciepłem wytworzonym w wyniku doprowadzenia do tego obszaru skoncentrowanej wiązki promieniowania laserowego o bardzo dużej gęstości mocy, rzędu $10^{2} \div 10^{11} \mathrm{~W} / \mathrm{mm}^{2}$ [4]. Spawanie laserowe może być prowadzone techniką spawania bez materiału dodatkowego $z$ oczkiem spoiny (grubość złączy do $20 \div 30 \mathrm{~mm}$ ) lub $z$ jeziorkiem spoiny (grubość złączy

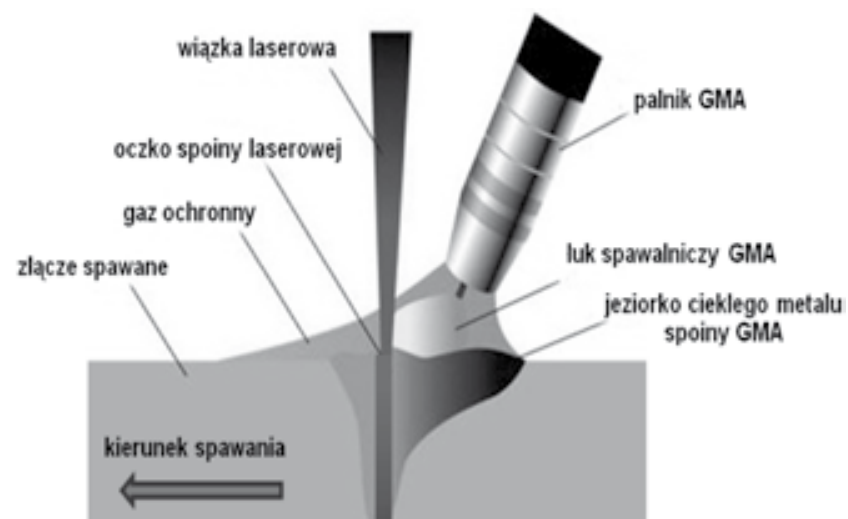

Rys. 2. Schemat spawania hybrydowego LHW [6]

Fig. 2. Scheme of LHW hybrid welding [6]

$3 \div 5 \mathrm{~mm}$ ), jednostronnie lub dwustronnie (rys. 1). W przypadku złączy o większej grubości, szczególnie zaś złączy konstrukcji ze stali trudno spawalnych o wysokiej granicy plastyczności, prowadzone jest coraz częściej spawane z oczkiem spoiny z materiałem dodatkowym lub spawanie hybrydowe - LHW - spawanie laserowe + spawanie GMA (rys. 2) [4].

Technologie laserowe tworzenia warstw wierzchnich części maszyn i urządzeń rozwijane są od wielu lat, przynosząc bardzo wymierne efekty ekonomiczne w wyniku znacznego zwiększenia właściwości trybologicznych, odporności na korozję, żarowytrzymałości

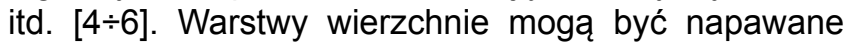
w zasadzie wszystkimi znanymi materiałami metalowymi i cermetalowymi, o grubości od dziesiętnych części milimetra do nawet powyżej $10 \mathrm{~mm}$ techniką napawania wielowarstwowego, zapewniając jednocześnie bardzo dokładne sterowanie udziałem materiału podłoża w nakładanej warstwie, od 2 do $90 \%$ (rys. 3). Tak niski udział materiału podłoża sprawia, że już w pierwszej warstwie można uzyskać wymagany skład chemiczny warstwy wierzchniej. Jeżeli wymagane jest wytworzenie warstwy wierzchniej o małej grubości, nawet rzędu kilku $\mu \mathrm{m}$, lecz o wyższych właściwościach użytkowych niż materiał podłoża, na powierzchniach roboczych części maszyn i urządzeń niezastąpione są techniki laserowe stopowania, przetapiania, czy coraz powszechniej stosowanej obróbki cieplnej (rys. 4) [5].

\section{Przemysłowe zastosowania technologii laserowych}

\section{Spawanie laserowe}

W budowie nowoczesnych maszyn i urządzeń coraz częściej wymagane jest użycie blach w arkuszach o gabarytach, których dla danej grubości nie da się wyprodukować w technologii walcowania (tabl. I). Wtedy konieczne jest łączenie doczołowo arkuszy w celu uzyskania wymiarów wymaganych przez konstruktorów maszyn i urządzeń. Technologia spawania 

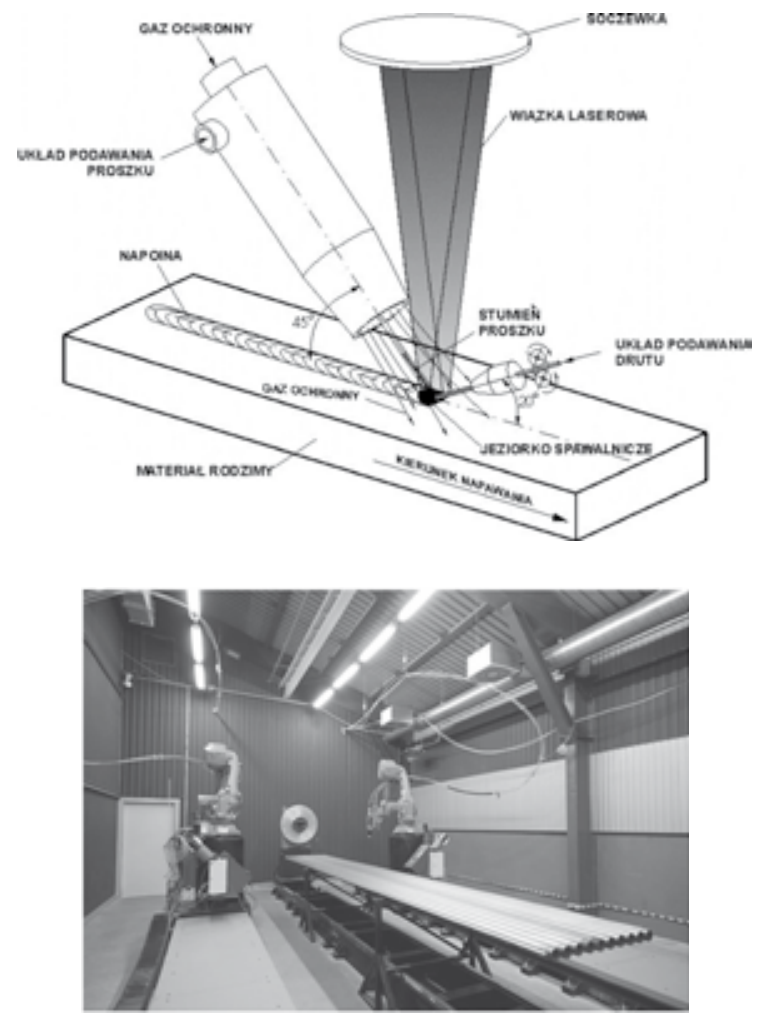

Rys. 3. Schemat procesu napawania laserowego $z$ jednoczesnym podawaniem materiałów dodatkowych: proszku i drutu do jeziorka ciekłego metalu warstwy wierzchniej oraz widok stanowiska do tego procesu w Plasma SYSTEM S.A. [7]

Fig. 3. Scheme of laser cladding process with simultaneous wire and powder feeding to the molten welding pool of surface layer and the view of laser cladding station at Plasma SYSTEM S.A. [7]

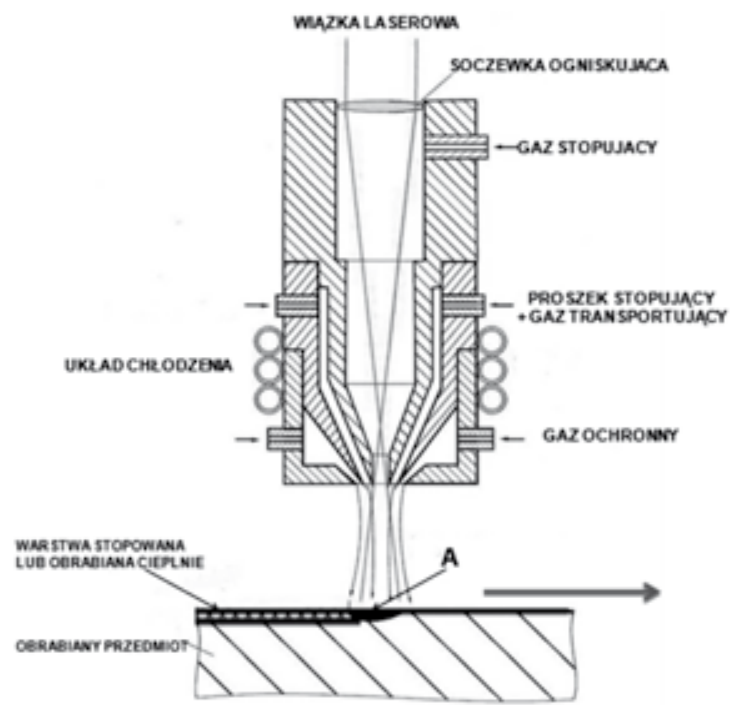

Rys. 4. Schemat procesu laserowego stopowania lub obróbki cieplnej $z$ podawaniem materiału stopującego $w$ postaci proszku i/lub gazu osłonowego do jeziorka ciekłego metalu warstwy wierzchniej. Obszar, A: proces stopowania - jeziorko ciekłego metalu, proces obróbki cieplnej - warstwa nagrzana do temp. obróbki, np. temp. hartowania [6]

Fig. 4. Scheme of laser surface alloying or heat treatment process with feeding of alloying material in form of powder and/or shield gas to the molten welding pool of surface layer. Area A: alloying process - molten welding pool, heat treatment process - surface layer heated to treatment temperature, e.g. temperature of hardening [6] laserowego umożliwia wykonanie między blachami złącza doczołowego o bardzo wysokiej jakości bez materiału dodatkowego i konieczności obróbki mechanicznej po spawaniu (tabl. II, rys. 5). Ponadto mała ilość ciepła wprowadzana podczas spawania minimalizuje naprężenia i odkształcenia spawalnicze.

Blachy z cynku i stopów cynku są coraz częściej stosowane na elementy pokrycia dachów i elewacji budynków, instalacje rynnowe i konstrukcje instalacji chemicznych, z uwagi na bardzo wysoką odporność cynku na korozję ogólną, a zwłaszcza korozję atmosferyczną. Właściwości fizyczne cynku sprawiają, że spawanie złączy konstrukcji $z$ tego materiału jest utrudnione, głównie $z$ uwagi na niską temperaturę topnienia i parowania: $419^{\circ} \mathrm{C}$ i $907^{\circ} \mathrm{C}$ (tabl. III i IV). Spawanie złączy doczołowych blach ze stopów cynku prowadzone jest zwykle metodą GTA ,PTA lub spawania gazowego. Możliwe jest również wykonywanie złączy zakładkowych blach za pomocą zgrzewa-

Tablica I. Skład chemiczny materiałów badanych blach S355J2C+M Table I. Chemical composition of tested plates S355J2C+M

\begin{tabular}{|c|c|c|c|c|c|}
\hline $\mathrm{C}$ & $\mathrm{Si}$ & $\mathrm{Mn}$ & $\mathrm{P}$ & $\mathrm{S}$ & $\mathrm{Cu}$ \\
\hline $\max$. & $\max$. & $\max$. & $\max$. & $\max$. & $\max$. \\
0,2 & 0,55 & 1,6 & 0,03 & 0,03 & 0,55 \\
\hline
\end{tabular}
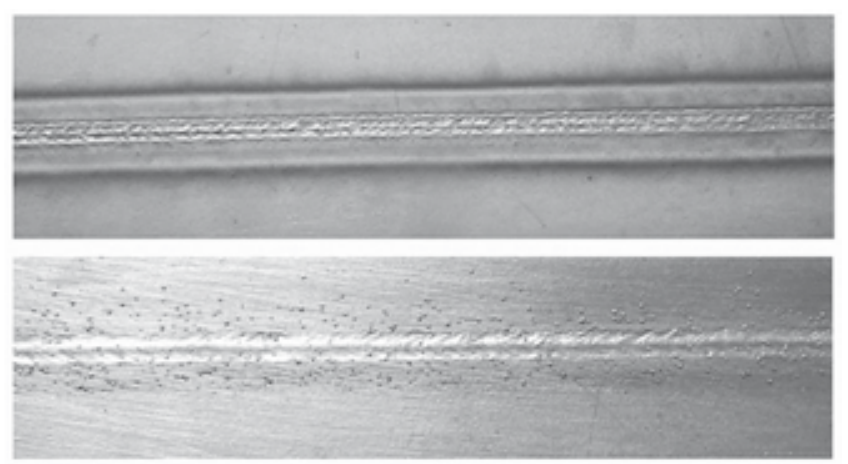

a)

b)
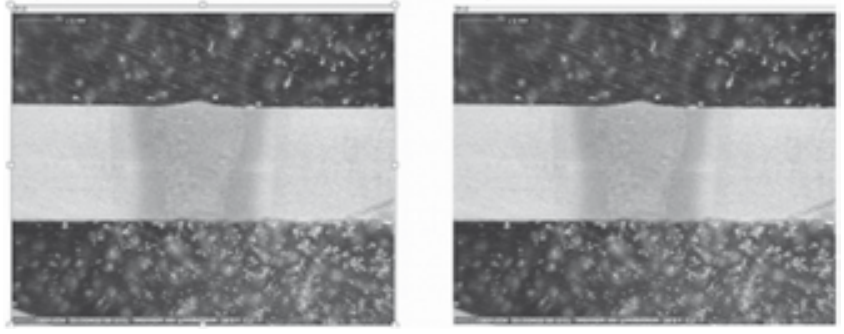

Rys. 5. Widok lica i grani spoiny czołowej oraz zgład metalograficzny złącza doczołowego spawanego laserem diodowym wysokiej mocy HPDL, długość ogniskowej wiązki $100 \mathrm{~mm}$, średnica ogniska wiązki $0,3 \mathrm{~mm}$, położenie ogniska na górnej powierzchni złącza blach, natężenie przepływu gazu osłonowego argonu - $12 \mathrm{l} / \mathrm{min}$ : a) moc wiązki lasera $1000 \mathrm{~W}$, prędkość spawania $10 \mathrm{~mm} / \mathrm{s}$, b) moc wiązki lasera $2000 \mathrm{~W}$, prędkość spawania $15 \mathrm{~mm} / \mathrm{s}$ [6]

Fig. 5. A view of face and root of the butt weld and a cross-section of the butt joint laser welded with high power diode laser HPDL, beam focal length $100 \mathrm{~mm}$, size of the focus $ø 0,3 \mathrm{~mm}$, position of the focus on the top the surface of the joint, intensity of the argon shielding gas flow - $12 \mathrm{l} / \mathrm{min}$ : a) laser beam power $1000 \mathrm{~W}$, welding speed 10 $\mathrm{mm} / \mathrm{s}, \mathrm{b}$ ) laser beam focus $2000 \mathrm{~W}$, welding speed $15 \mathrm{~mm} / \mathrm{s}$ [6] 
Tablica II. Średnie wartości pomiaru twardości HV1 badanej na przekroju złącza dla parametrów a) i b) wg rysunku 5

Table II. Average values of hardness HV1 tests examined on the cross-section of the joint for parameters a) and b) acc. to Fig. 5

\begin{tabular}{|c|c|c|}
\hline Obszar pomiaru & Parametry a) & Parametry b) \\
\hline Materiał rodzimy & 183 & 190 \\
\hline SWC & 255 & 254 \\
\hline Spoina & 361 & 375 \\
\hline
\end{tabular}
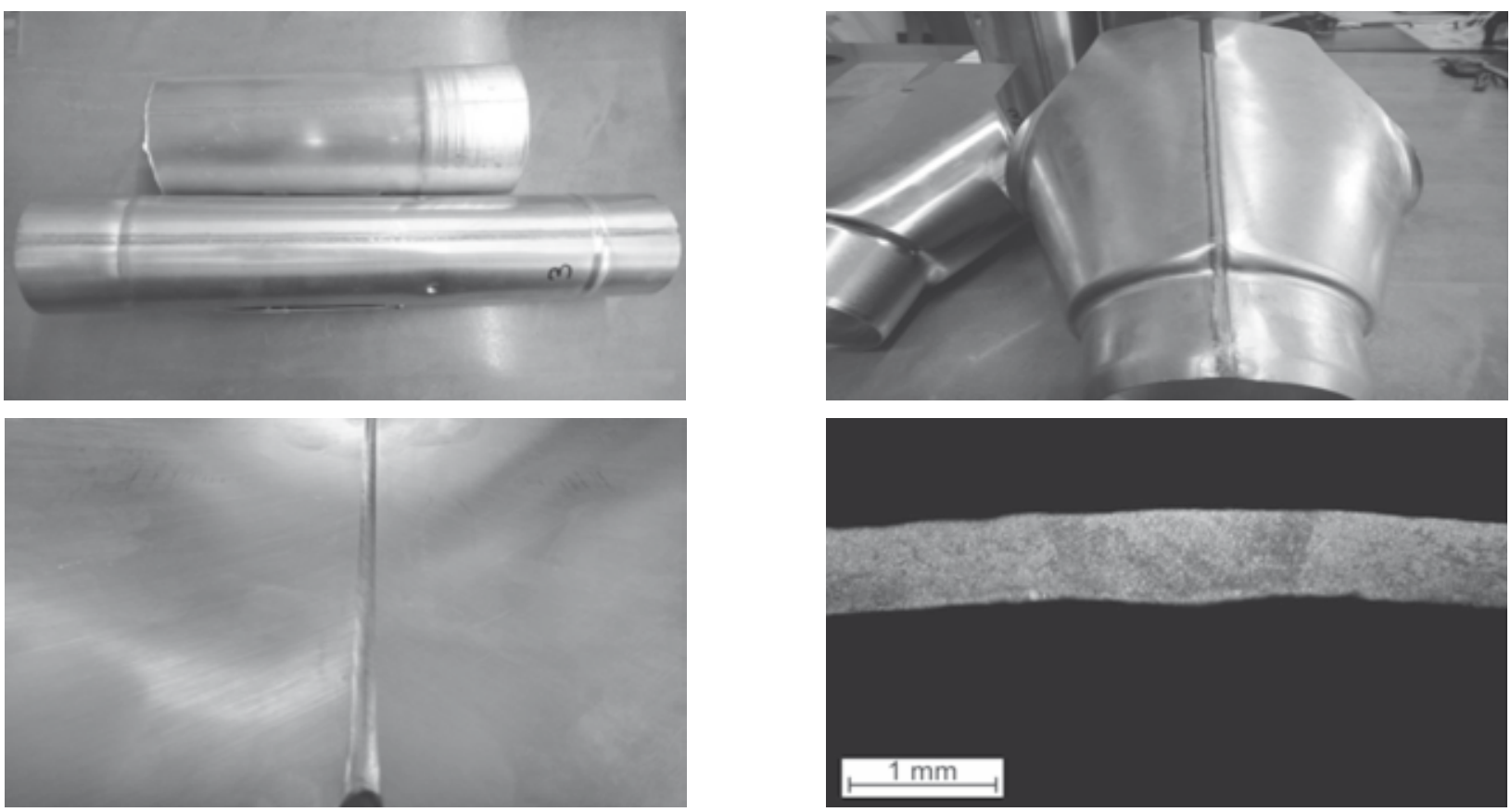

Rys. 6. Elementy instalacji rynnowej wykonane z blach ze stopu $\mathrm{Zn}-\mathrm{Ti}$, oraz widok lica spoiny i zgład makro złącza doczołowego spawanego laserem na ciele stałym, moc wiązki $180 \div 200 \mathrm{~W}$, prędkość spawania $0,8 \div 1,0 \mathrm{~m} / \mathrm{min}$, średnica wiązki 80 um, długość ogniskowej wiązki $223 \mathrm{~mm}$, położenie ogniska na górnej powierzchni złącza blach, natężenie przepływu gazu osłonowego argonu - $10 \mathrm{l} / \mathrm{min}$, natężenie przepływu powietrza dyszy poprzecznej - $12 \mathrm{l} / \mathrm{min}[6]$

Fig. 6. A view of elements of roof gutter installation made of zinc alloy $\mathrm{Zn}$-Ti sheets, and a view of the face of weld and the cross-section of butt joint laser welded with solid state laser, laser power $180 \div 200 \mathrm{~W}$, welding speed $0,8 \div 1,0 \mathrm{~m} / \mathrm{min}$, beam diameter $80 \mu \mathrm{m}$, focal length $223 \mathrm{~mm}$, position of the focus on the top the surface of the joint, intensity of the argon shielding gas flow $-10 \mathrm{l} / \mathrm{min}$, intensity of the cross jet air flow $-12 \mathrm{l} / \mathrm{min}[6]$

Tablica III. Właściwości fizyczne cynku

Table III. Physical properties of zinc

\begin{tabular}{|c|c|c|c|c|c|}
\hline $\begin{array}{c}\text { Temperatura } \\
\text { topnienia } \\
{ }^{\circ} \mathrm{C}\end{array}$ & $\begin{array}{c}\text { Temperatura } \\
\text { parowania } \\
{ }^{\circ} \mathrm{C}\end{array}$ & $\begin{array}{c}\text { Gęstość właściwa } \\
\mathrm{g} / \mathrm{cm}^{3}\end{array}$ & $\begin{array}{c}\text { Współczynnik } \\
\text { rozsz. liniowej } \\
10^{-6} \mathrm{~K}^{-1}\end{array}$ & $\begin{array}{c}\text { Współczynnik } \\
\text { przewodnictwa } \\
\text { cieplnego } \\
\text { W/mK }\end{array}$ & $\begin{array}{c}\text { Twardość } \\
\text { HB }\end{array}$ \\
\hline 419 & 907 & 7,14 & 39,7 & 113 & $32-40$ \\
\hline
\end{tabular}

Tablica IV. Właściwości mechaniczne i skład chemiczny materiałów badanych blach ze stopu cynku Zn-Ti o wymiarach 0,75x365 mm, wg atestu Huty Silesia

Table IV. Mechanical properties and chemical composition of tested zinc alloy $\mathrm{Zn}-\mathrm{Ti}$ sheet of dimensions $0,75 \times 365 \mathrm{~mm}$, according to Huta Silesia material certificate

\begin{tabular}{|c|c|c|c|c|c|c|c|c|c|c|}
\hline \multicolumn{3}{|c|}{ Właściwości mechaniczne } & \multicolumn{7}{c|}{ Skład chemiczny } \\
\hline $\begin{array}{c}\mathrm{R}_{\mathrm{m}} \\
\mathrm{MPa}\end{array}$ & $\begin{array}{c}\mathrm{R}_{0,2} \\
\mathrm{MPa}\end{array}$ & $\begin{array}{c}\mathrm{A}_{5} \\
\%\end{array}$ & $\begin{array}{c}\text { Twardość } \\
\mathrm{HV}\end{array}$ & $\mathrm{Pb}$ & $\mathrm{Cd}$ & $\mathrm{Fe}$ & $\mathrm{Cu}$ & $\mathrm{Ti}$ & $\mathrm{Al}$ & $\mathrm{Zn}$ \\
\hline 119,25 & 73,25 & 79,25 & 44,8 & 0,0004 & 0,0011 & 0,001 & 0,032 & 0,0192 & 0,0066 & 99,939 \\
\hline
\end{tabular}


nia oporowego punktowego i liniowego. Wyniki badań nad opracowaniem technologii spawania LB laserem o wysokiej jakości wiązki, rzędu $2 \mathrm{~mm} x$ mrad, złączy doczołowych elementów rynnowych z blach ze stopu cynku Zn-Ti przedstawiono na rysunku 6.

\section{Napawanie laserowe}

Technologia napawania laserowego umożliwia wytworzenie użytkowej warstwy wierzchniej na nowych elementach oraz precyzyjną regenerację części maszyn i urządzeń. Precyzja oraz elastyczność procesu umożliwia regenerację części, których naprawa do tej pory nie była technologicznie możliwa lub ekonomicznie uzasadniona oraz zastąpienie nim konwencjonalnych technologii regeneracji w celu zwiększenia jakości wykonanej naprawy oraz skrócenia jej czasu. Przekłada się to bezpośrednio na zmniejszenie kosztów nie tylko samej regeneracji, ale również kosztów związanych z przestojem maszyn. Oszczędności wynikają również ze skrócenia czasu obróbki mechanicznej po napawaniu laserowym w porównaniu z konwencjonalnymi technologiami napawania, co wynika z możliwości nakładania bardzo równomiernych warstw oraz ograniczenia naddatku na obróbkę mechaniczną (rys. $7 \div 11$ ).

\section{Laserowa obróbka cieplna warstw wierzchnich}

Technologia hartowania laserowego jest technologią zdecydowanie mniej energochłonną niż tradycyjne metody hartowania piecowego i indukcyjnego [4]. Energia
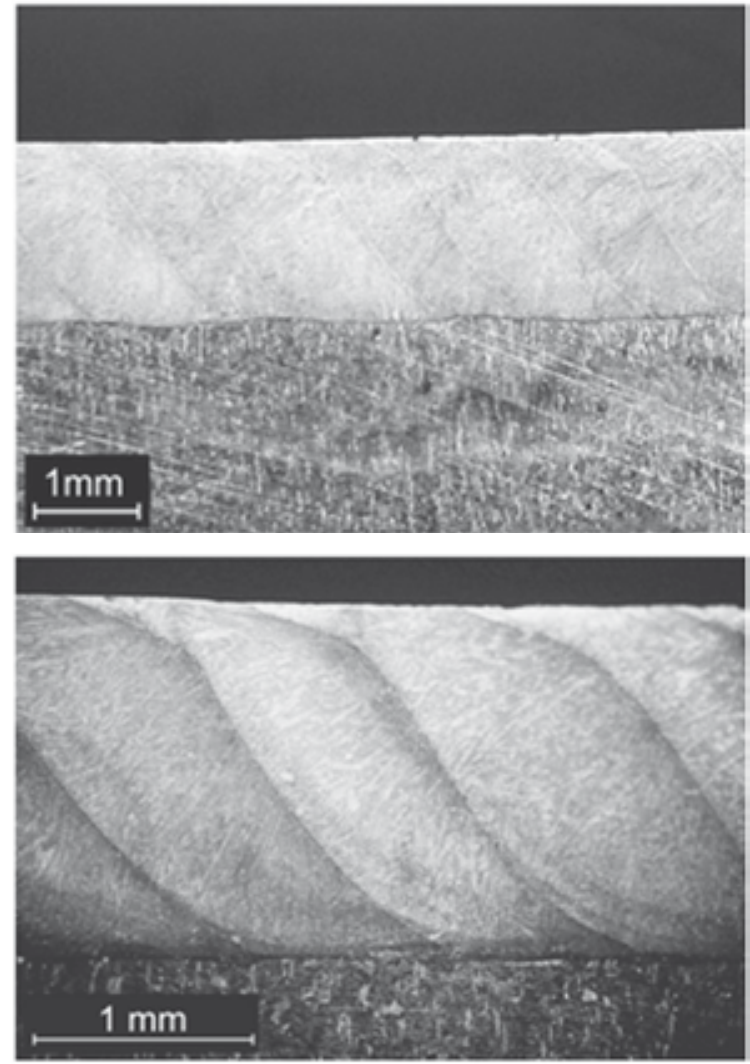

Rys. 7. Warstwa wykonana technologią napawania laserowego [6] Fig. 7. Layer cladded using laser technology [6]
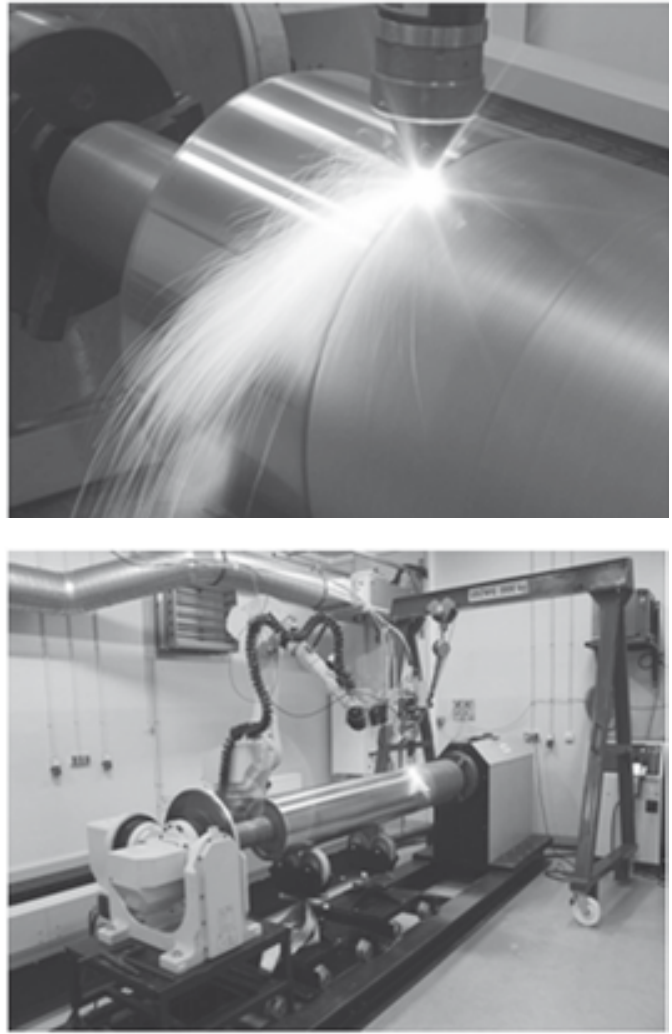

Rys. 8. Proces napawania laserowego na wielkogabarytowym elemencie cylindrycznym [6]

Fig. 8. Laser cladding process on a large-size cylindrical element [6]
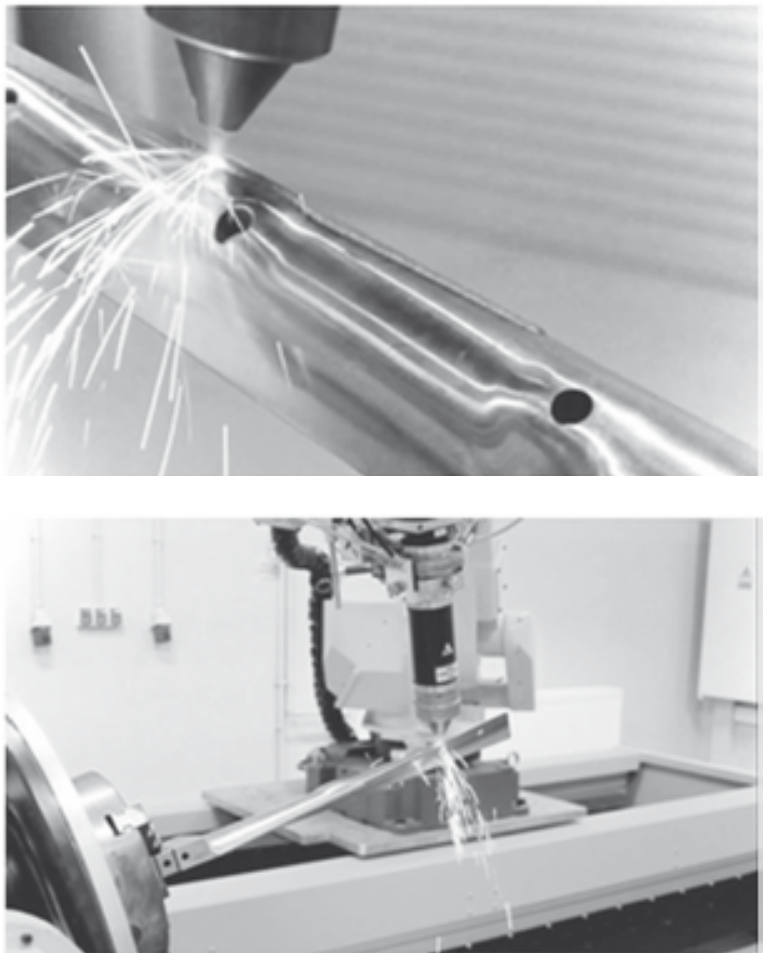

Rys. 9. Regeneracja krawędzi natarcia łopatki ze stali nierdzewnej materiałem na bazie kobaltu oraz zrobotyzowane stanowisko do regeneracji łopatek technologią napawania laserowego [6]

Fig. 9. Regeneration of the edge of stainless steel blade using a cobalt base material and a view of a robotized station for regeneration of blades with laser cladding technology [6] 

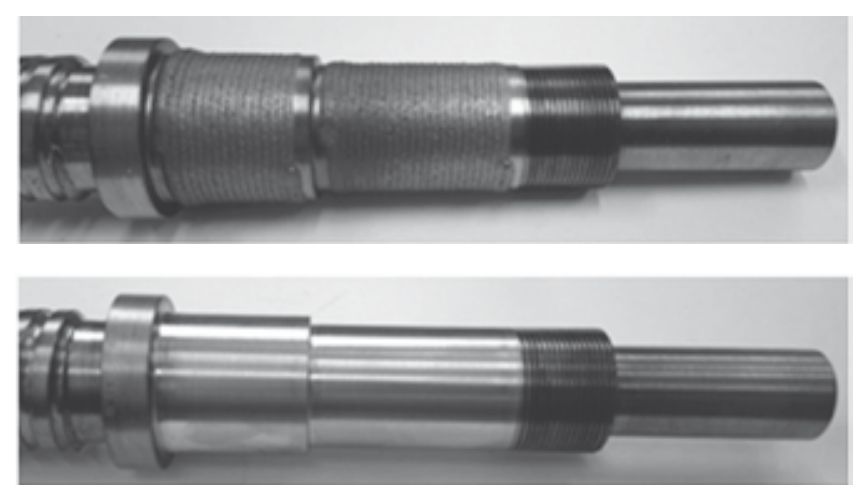

Rys. 10. Wał naprawiony metodą napawania laserowego. Widok wału po procesie oraz po obróbce mechanicznej [6]

Fig. 10. A shaft repaired using laser cladding technology. A view of the shaft after machining [6]
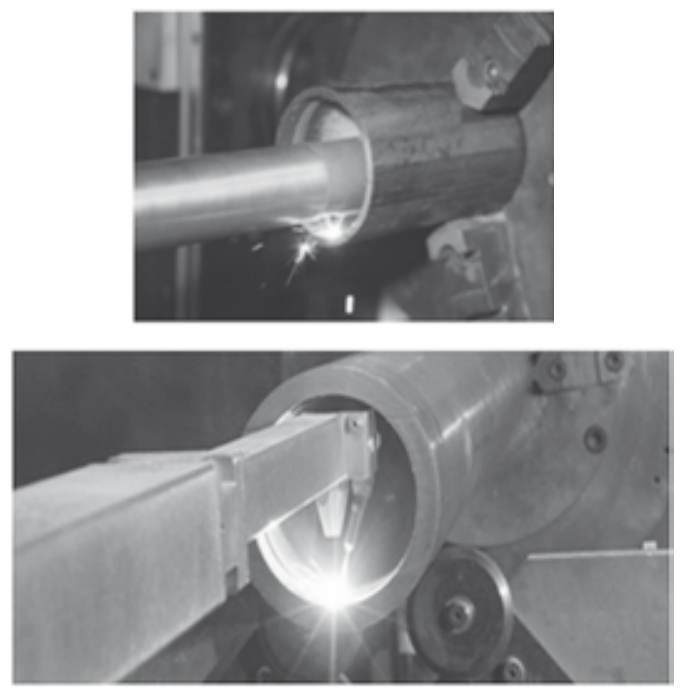

Rys. 11. Napawanie laserowe wewnętrznej średnicy rury [6] Fig. 11. Laser cladding of internal tube diameter [6]

wiązki laserowej jest absorbowana wyłącznie przez obrabianą warstwę wierzchnią elementu przeznaczoną do hartowania, a więc energia jej jest zużywana wyłącznie na nagrzewanie $z$ dużą prędkością warstwy wierzchniej, a rdzeń elementu pozostaje w stanie suro-

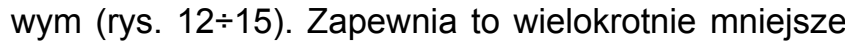
zużycie energii w stosunku do tradycyjnych procesów hartowania, a zwłaszcza hartowania piecowego, gdzie cały element nagrzewany jest $w$ piecu do temp. hartowania. Przykładem obrazującym zalety hartowania laserowego jest proces hartowania czopu wału ze stali narzędziowej o wymiarach 100x75 mm (rys. 16). Zastosowanie hartowania laserem o mocy ciągłej wiązki laserowej $4 \mathrm{~kW}$ umożliwia zahartowanie powierzchni zewnętrznej na wymaganą głębokość $2 \mathrm{~mm}$ w czasie ok. 70 s, przy zużyciu energii ok. 700 kJ [4]. Czas hartowania piecowego tego elementu wynosi ok. $2 \mathrm{~h}$, przy zużyciu energii rzędu kilkudziesięciu MJ. Kolejnym przykładem jest hartowanie wału silnika o masie $1000 \mathrm{~kg}$. Hartowanie piecowe takiego elementu trwa ok. 4 h. Natomiast hartowanie warstwy wierzchniej wału silnika wiązką lasera o mocy $4 \mathrm{~kW}$ umożliwia prowadzenie procesu z wydajnością $2 \mathrm{dm}^{2} / \mathrm{min}$ i proces

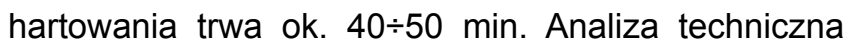
i ekonomiczna wskazuje, że wydajność procesu hartowania laserowego i efektywność jego stosowania w porównaniu $z$ hartowaniem piecowym i indukcyjnym wzrasta wraz ze wzrostem masy elementu. llość zużywanej energii jest od kilku do kilkudziesięciu razy mniejsza niż w przypadku hartowania metodami tradycyjnymi [4].

Podczas hartowania laserowego do elementu wprowadzana jest znacznie mniejsza ilość ciepła niż w konwencjonalnych procesach hartowania. Przekłada się to na zdecydowane zmniejszenie naprężeń wewnętrznych, co znacznie obniża odkształcenia przedmiotów obrabianych cieplnie wiązką laserową. Efektem tego jest wyeliminowanie dodatkowych operacji technologicznych po samym procesie hartowania, takich jak obróbka wykańczająca, prostowanie, odprężanie. Przy projektowaniu i produkcji wyrobu zbędne jest więc uwzględnianie naddatków na obróbkę i dlatego laserowa obróbka cieplna może być łatwo zintegrowana z procesem ich produkcji. Wyeliminowanie obróbki wykańczającej już zahartowanej twardej powierzchni elementu $w$ istotnym stopniu zmniejsza czas $i$ energochłonność procesu produkcyjnego. Samoczynne chłodzenie się elementów w hartowaniu laserowym powoduje, że całkowicie wyeliminowane jest stosowanie wody i oleju w procesie [6]. Wiązką laserową można obrabiać całą powierzchnię roboczą przedmiotów takich jak np.: wałki, łłoczyska, nurniki, matryce, stemple itp., lub tylko część powierzchni roboczej, jak np. krawędzie tnące nożyc czy powierzchnię trącą pierścienia tłokowego (tabl. V i VI).

Tablica V. Wpływ parametrów procesu laserowego hartowania powierzchni płytek ze stali narzędziowej WNL i NC11 oraz rodzaju osłony gazowej na twardość zahartowanej warstwy wierzchniej $[4,6]$ Table V. Influence of laser hardening with diode laser HPDL of surface of a tool steel plates WNL and NC11 process parameters and the type of shielding gas on the hardened layer hardness $[4,6]$

\begin{tabular}{|c|c|c|c|c|c|}
\hline \multirow{3}{*}{$\begin{array}{c}\text { Moc } \\
\text { lasera } \\
\text { W }\end{array}$} & \multirow{3}{*}{$\begin{array}{l}\text { Prędkość } \\
\text { przesuwu } \\
\text { wiązki } \\
\text { laserowej } \\
\mathrm{m} / \mathrm{min}\end{array}$} & \multicolumn{4}{|c|}{$\begin{array}{c}\text { Twardość warstwy zahartowanej } \\
\text { HV0,2 }\end{array}$} \\
\hline & & \multicolumn{2}{|c|}{ WNL } & \multicolumn{2}{|c|}{ NC11 } \\
\hline & & argon & azot & argon & azot \\
\hline 400 & 0,2 & 731,15 & 777,1 & 468,5 & 435,6 \\
\hline 1200 & 0,2 & 637,3 & 766,7 & 417,7 & 431,25 \\
\hline 2000 & 0,2 & 653,25 & 712,95 & 463,1 & 447,95 \\
\hline 2000 & 0,1 & 747,45 & 693,5 & 516,7 & 450,3 \\
\hline
\end{tabular}

Uwaga: Twardość materiału rodzimego WNL - $257 \mathrm{HV0,2}$;

NC11 - 295 HV0,2. 

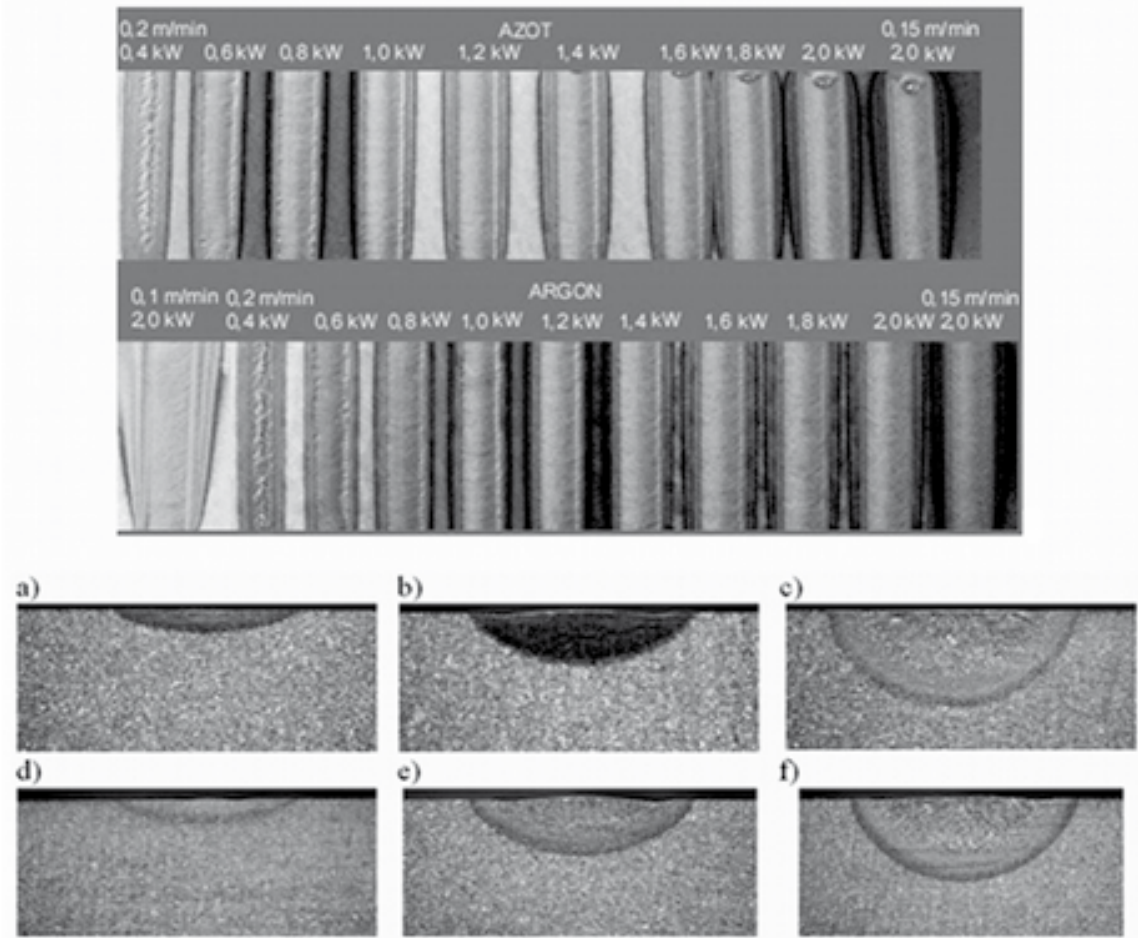

Rys. 12. Wpływ parametrów procesu laserowego hartowania powierzchni płytki ze stali narzędziowej WNL laserem diodowym HPDL na kształt ściegu w atmosferze argonu: a) 0,4 kW, 0,2 m/min; b) 1,4 kW, 0,2 m/min; c) 2,0 kW 0,1 m/min; oraz w atmosferze azotu: d) 0,4 kW $0,2 \mathrm{~m} / \mathrm{min}$; e) $1,4 \mathrm{~kW}, 0,2 \mathrm{~m} / \mathrm{min}$; f) $2,0 \mathrm{~kW}, 0,1 \mathrm{~m} / \mathrm{min}$; pow. 10x [4, 6]

Fig. 12. Influence of laser hardening with diode laser HPDL of surface of a tool steel plate WNL process parameters on the shape of the seam in the atmosphere of argon: a) $0,4 \mathrm{~kW}, 0,2 \mathrm{~m} / \mathrm{min}$; b) $1,4 \mathrm{~kW}, 0,2 \mathrm{~m} / \mathrm{min}$; c) 2,0 kW, 0,1 m/min; in the nitrogen atmosphere; d) $0,4 \mathrm{~kW}$, $0,2 \mathrm{~m} / \mathrm{min}$; e) $1,4 \mathrm{~kW}, 0,2 \mathrm{~m} / \mathrm{min}$;) $2,0 \mathrm{~kW}, 0,1 \mathrm{~m} / \mathrm{min}$; magn. 10x [4, 6]

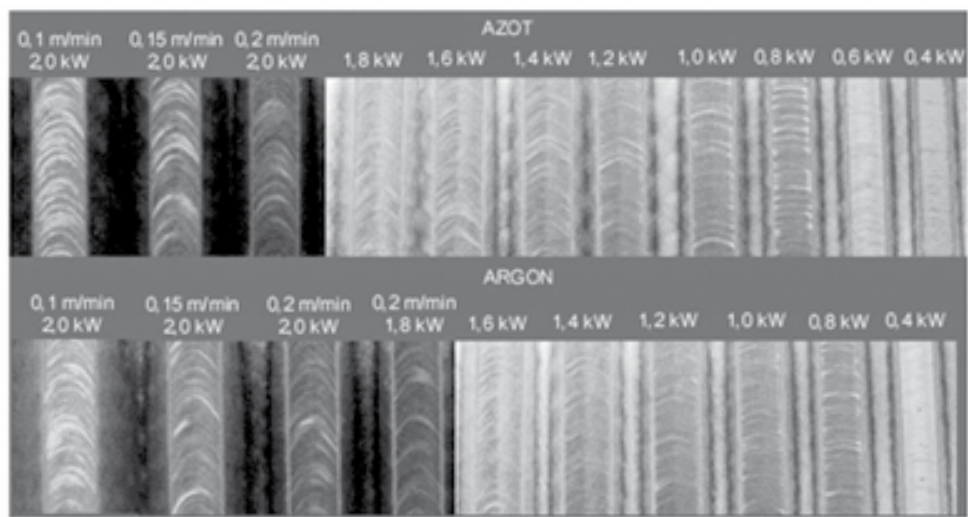

a)

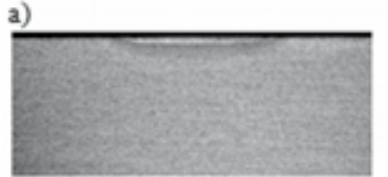

d)

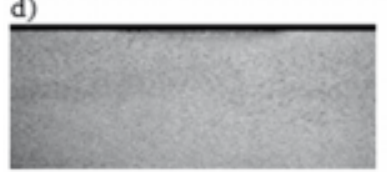

b)

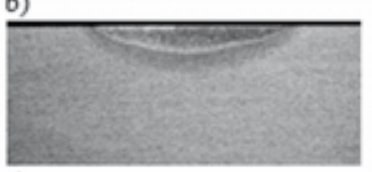

e)

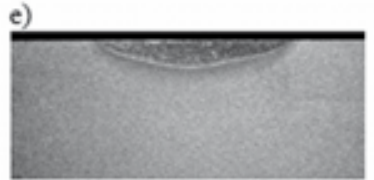

c)

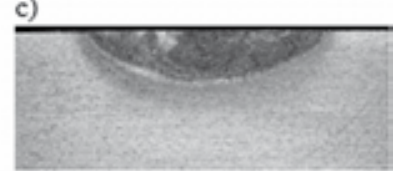

f)

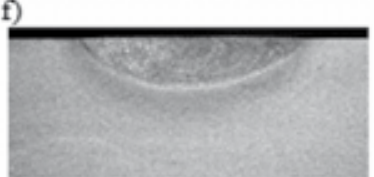

Rys. 13. Wpływ parametrów procesu laserowego hartowania powierzchni płytki ze stali narzędziowej NC11 laserem diodowym HPDL na kształt ściegu w atmosferze argonu: a) 0,4 kW, 0,2 m/min; b) 1,4 kW, 0,2 m/min; c) 2,0 kW, 0,1 m/min; oraz w atmosferze azotu: d) 0,4 kW, $0,2 \mathrm{~m} / \mathrm{min}$; e) $1,4 \mathrm{~kW}, 0,2 \mathrm{~m} / \mathrm{min}$; f) $2,0 \mathrm{~kW}, 0,1 \mathrm{~m} / \mathrm{min}$; pow. 10x [4, 6]

Fig. 13. Influence of laser hardening with diode laser HPDL of surface of a tool steel plate NC11 process parameters on the shape of the seam in the atmosphere of argon: a) $0,4 \mathrm{~kW}, 0,2 \mathrm{~m} / \mathrm{min}$; b) $1,4 \mathrm{~kW}, 0,2 \mathrm{~m} / \mathrm{min}$; c) 2,0 kW, 0,1 m/min; in the nitrogen atmosphere: d) $0,4 \mathrm{~kW}$, $0,2 \mathrm{~m} / \mathrm{min}$; e) $1,4 \mathrm{~kW}, 0,2 \mathrm{~m} / \mathrm{min}$; f) $2,0 \mathrm{~kW}, 0,1 \mathrm{~m} / \mathrm{min}$; magn. 10x [4, 6] 
Tablica VI. Warunki technologiczne obróbki cieplnej powierzchniowej laserem diodowym HPDL materiałów różnych $[4,6]$

Table VI. Technological conditions of surface heat treatment with diode laser HPDL for different kind of materials $[4,6]$

\begin{tabular}{|c|c|c|c|c|c|c|}
\hline $\begin{array}{c}\text { Rodzaj } \\
\text { materiału }\end{array}$ & $\begin{array}{c}\text { Grubość } \\
\text { warstwy } \\
\mathrm{mm}\end{array}$ & $\begin{array}{c}\text { Szerokość war- } \\
\text { stwy } \\
\mathrm{mm}\end{array}$ & $\begin{array}{c}\text { Moc } \\
\text { wiązi } \\
\mathrm{kW}\end{array}$ & $\begin{array}{c}\text { Wymiary } \\
\text { ogniska } \\
\mathrm{mm}\end{array}$ & $\begin{array}{c}\text { Prędkość } \\
\text { przesuwu } \\
\mathrm{mm} / \mathrm{min}\end{array}$ & $\begin{array}{c}\text { Twardość } \\
\text { warstwy } \\
\text { HV0,5 }\end{array}$ \\
\hline Stal 0,45\%C & 0,9 & 6,0 & 1,4 & $2,0 \times 6,0$ & 500 & $1000 \div 1200$ \\
\hline Żeliwo sferoidalne & $0,4 \div 1,0$ & 6,0 & 1,4 & $2,0 \times 6,0$ & $50 \div 200$ & $600 \div 650$ \\
\hline $\begin{array}{c}\text { Pierścień tłokowy } \\
\text { ze stali 55Si7 }\end{array}$ & $0,1 \div 0,5$ & 1,36 & 1,37 & $1,8 \times 3,8$ & 2115 & $800 \div 900$ \\
\hline $\begin{array}{c}\text { Stop tytanu } \\
\text { Ti-6Al-4V* }\end{array}$ & $0,3 \div 0,9$ & 7,0 & 0,4 & $2,0 \times 7,0$ & $100 \div 500$ & $540 \div 600$ \\
$\mathrm{HV} 0,05$
\end{tabular}

* Dodatkowy nadmuch na powierzchnię jeziorka ciekłego metalu azotu o natężeniu przepływu $4 \div 5 \mathrm{I} / \mathrm{min}$.

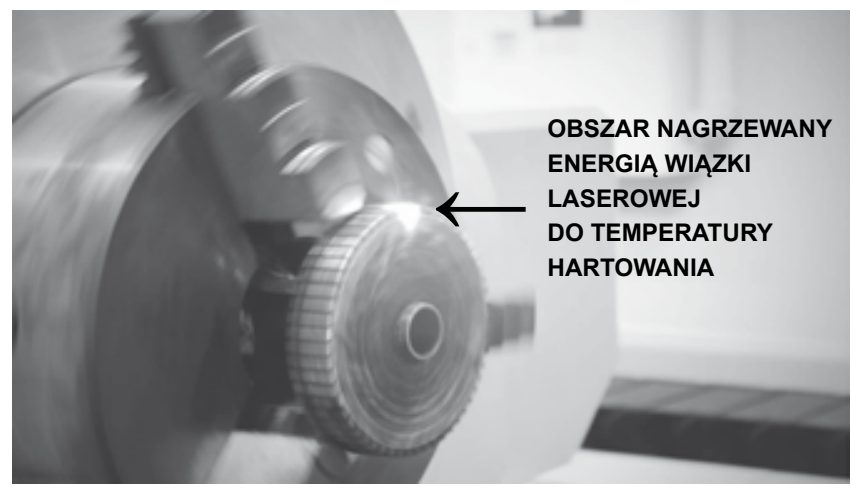

Rys. 14. Hartowanie laserem diodowym dużej mocy HPDL zębów koła wykonanego ze stali 45 [6]

Fig. 14. Laser hardening process with high power diode laser HPDL of the teeth of a gear wheel made of steel 45 [6]

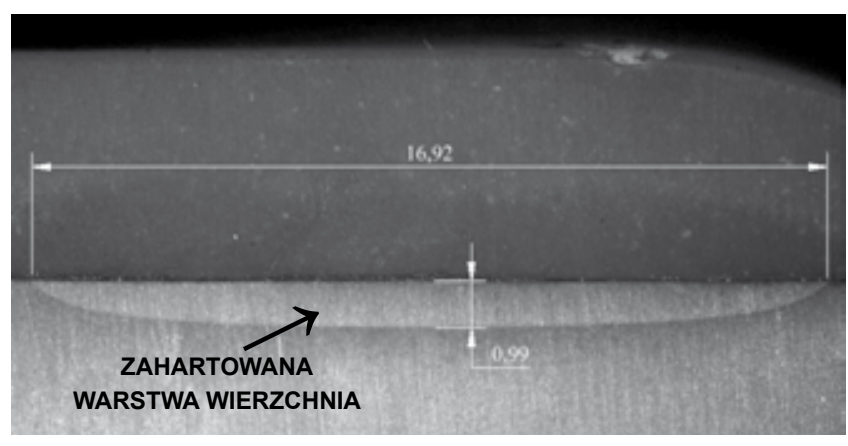

Rys. 15. Obszar zahartowany laserem HPDL, materiał rodzimy $20 \mathrm{MnCr} 5$, prędkość hartowania $3 \mathrm{~mm} / \mathrm{s}$, moc lasera $800 \mathrm{~W}$, wielkość ogniska 1,2×17,0 mm [6]

Fig. 15. Hardened area with HPDL laser, base material $20 \mathrm{MnCr} 5$, hardening speed $3 \mathrm{~mm} / \mathrm{s}$, laser beam power $800 \mathrm{~W}$, focus size $1,2 \times 17,0 \mathrm{~mm}[6]$

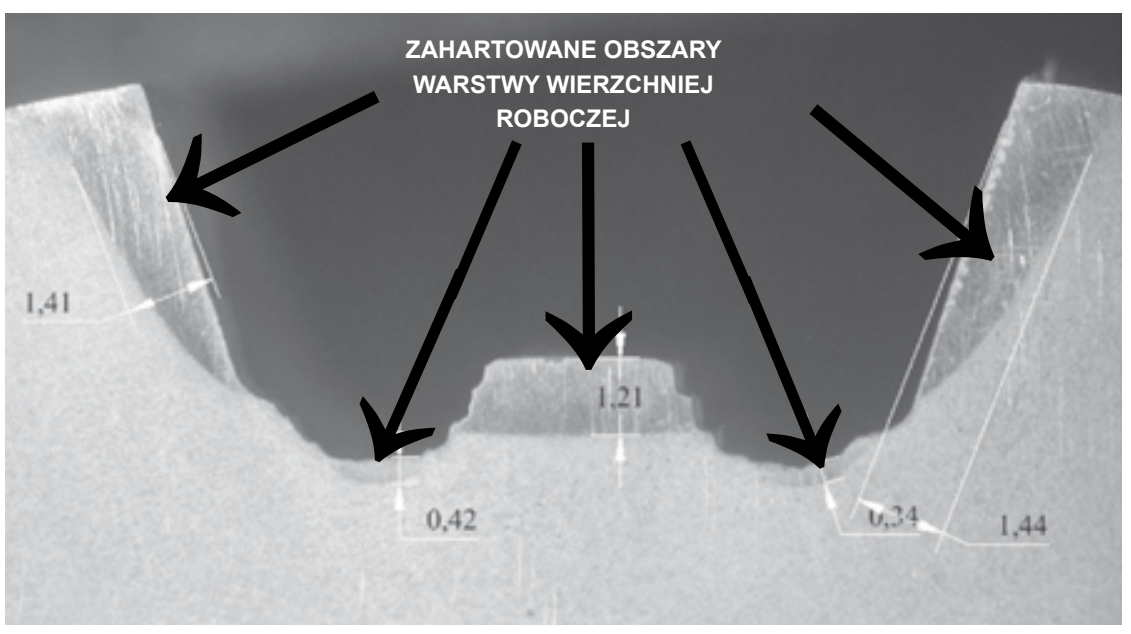

Rys. 16. Wielowypust wału napędowego ze stali $42 \mathrm{CrMoS4}$, którego wybrane powierzchnie robocze zahartowano laserem diodowym dużej mocy HPDL moc wiązki laserowej 1200 W, prędkość przesuwu wiązki $10 \mathrm{~mm} / \mathrm{s}$, średnica ogniska $7 \mathrm{~mm}$, gaz osłonowy argon o natężeniu przepływu $14 \mathrm{l} / \mathrm{min}[6]$

Fig. 16. Splines of a shaft made of $42 \mathrm{CrMoS} 4$ steel, on which selected working surfaces were hardened with high power diode laser HPDL, laser beam power $1200 \mathrm{~W}$, laser beam movement speed $10 \mathrm{~mm} / \mathrm{s}$, focus diameter $7 \mathrm{~mm}$, shielding gas flow intensity $14 \mathrm{l} / \mathrm{min}$ [6] 


\section{Podsumowanie}

Przedstawione wyniki badań i zastosowania pokazują możliwości technologiczne wykorzystania technologii laserowych w przemyśle. Technologie laserowego spawania, napawania i obróbki cieplnej mają liczne zalety, które stanowią o ich wyższości nad technologiami konwencjonalnymi. Są to w przypadku:

- spawania: duża gęstość mocy i prędkość procesu, możliwość spawania samą wiązką (bez materiału dodatkowego), wysoka precyzja i czystość procesu, możliwość łączenia materiałów trudno spawalnych, różnoimiennych oraz materiałów o różnych grubościach;

- hartowania: możliwość selektywnego hartowania wybranych obszarów elementu, uzyskuje się wówczas drobniejszą strukturę martenzytyczną o wyższej twardości niż w przypadku hartowania piecowego i indukcyjnego, możliwość hartowania elementów wykonanych „na gotowo", bez konieczności obróbki mechanicznej po hartowaniu, w przeważającej większości przypadków nie stosuje się żadnego medium chłodzącego, brak lub minimalne odkształcenia cieplne hartowanych elementów; jest też możliwość hartowania materiałów nawet o zawartości $0,22 \%$ węgla.

- napawania: łatwość wykonania napoiny z materiałów znacznie różniących się składem chemicznych od materiałów podłoża, otrzymuje się wtedy napoiny o najlepszej jakości ze wszystkich procesów napawania o bardzo drobnoziarnistej strukturze. Udział materiału podłoża w napoinie jest bardzo mały, (nawet poniżej 3\%), zwykle $5 \div 10 \%$. Możliwe jest tworzenie cienkich powłok o grubości od 0,1 mm do kilku (nawet kilkunastu) milimetrów - większe grubości można napawać wielowarstwowo, metoda zapewnia bowiem bardzo małe oddziaływanie ciepła (SWC na poziomie $0,1 \div 0,5 \mathrm{~mm}$ ) na nakładany materiał oraz minimalne naprężenia i odkształcenia spawalnicze.

\section{Literatura}

[1] Bernstain J.: Albert Einstein i granice fizyki. Świat Książki, Warszawa 2008.

[2] Maiman T.H.: Stimulated Optical Radiation in Ruby. Nature, 1960, 187 (4736), 493- 494.

[3] Houldcroft P.: Gas-jet laser cutting. British Welding Journal, August 1967, s. 443 .
[4] Klimpel A.: Technologie laserowe. Wyd. Politechniki Śląskiej. Gliwice 2012.

[5] Nowacki J.: Spiekane metale i kompozyty z osnową metaliczną. WNT, Warszawa 2005.

[6] Materiały badawcze firmy LaserTec www.lasertec.pl.

[7] Dzięki uprzejmości firmy Plasma System S.A. www.plasmasystem.pl.

\section{Naukowo-Techniczna Konferencja Spawalnicza Spawalnictwo w Trzech Żywiołach: Ziemia - Woda - Powietrze Gdańsk-Sobieszewo, 14-16 października 2013}

\section{Artykuły opublikowane w Advances in Materials Science No 3(37) 2013:}

G. Gontarz, D. Golański, T. Chmielewski

Properties of Fe-Al type intermetallic layers produced by AC TIG method

I. Pikos, R. Kocurek, J. Adamiec

Perspectives of materials for fin tubes

\section{R. Kocurek, J. Adamiec}

Manufacturing technologies of finned tubes

M. Korzeniowski, T. Piwowarczyk, P. Kustroń, A. Czubak Low-energy welding methods used for semi-automatic thin-walled automotive steels
T. Piwowarczyk, M. Korzeniowski, P. Kustroń, M. Gąbka Pulsed arc welding applied to robotized joining of thin car-body steel sheets

\section{S. Krajewski, J. Nowacki}

Preparation of aluminium foam edges for welding

K. Pańcikiewicz, A. Zielińska-Lipiec, E. Tasak Cracking of high-strength steel welded joints 